\title{
Measurement issues of the social class in social psychology of education: Is it a category mistake?
}

\begin{abstract}
The present article discusses the measurement of social class in the social psychology of education research. It was evident that social class experiences are conflated with the socioeconomic status (SES) indicators and the subjective measure of the class context was underrepresented. However, this was discussed in Rubin et al (2014) about the intersectional nature of social class taking into account both objective and subjective indicators. The derivation of the social class experience from the objective and subjective measures were critically discussed. An effort was made to understand whether these translations are category mistake or not. Three trajectories will be utilized to address the category mistake, that is, 1) subjectivity and objectivity debate in the measurement of social class in social psychology of education, 2) debates encircling around the position of social psychology and its underutilized concept such as social class as scientifically objective facets in social sciences and 3) operationalism of social class and category mistake.
\end{abstract}

Keywords: social class, SES, category mistake, social psychology of education, India

In modern social psychological research, the SES was measured through the objective indicators in the last couple of decades. The measure of SES seems to be important in understanding the person's standing on the social hierarchy with the help of primary tripartite indicators of income, education, and occupation (see Davey Smith et al., 1998; Lareau \& Conley, 2008; Stephens, Markus \& Fryberg, 2012). These objective measures of SES were heavily relied to explain some psychological experiences like teacher judgment of pupil aptitude, classroom behaviour and achievement level (Hoge, 1983; also Gaines \& Davis, 1990; White, 1980; Sirin, 2005; see Winne \& Nesbit, 2010), intelligence (see Nettelbeck \& Wilson, 2010), school readiness (Hochschild, 2003; McLoyd, 1998), self-efficacy (Arnold \& Doctoroff, 2003 ) etc. Some of the observations showed that objective indicators result in contrary psychological outcomes as compared with the subjective indicators such as perception about one's standing on the social ladder (e.g. Scott \& Leonhardt, 2005). Nagel (1974) argued that the claim of being an objective observer having the consciousness about the others' mental states may be a myth. He talked about the subjective 'character of experience' (p. 436). In a similar way, the epistemological approach of social psychologists as an objective observer of the social class through the indicators of SES can be challenging.
Recently, the trend to explore the intersectional nature of objective and subjective indicators are observed pertaining to the critiques call for the subjective understanding of social class (Rubin et al., 2014; see also see also Day, Rickett \&Woolhouse, 2014; Kraus \& Stephens, 2012). It is a matter of controversy whether the assigned criteria to understand the subjective SES truly captures the social class experiences or not. Though the arguments for subjective SES were neither in minority nor new and people in different disciplines were exploring it (see Chapin, 1935). According to Wright (2015) the approaches of understanding the social class were evident in three sociological analyses, 1) stratification approaches to class which define class in terms of individual attributes and conditions, 2) Weberian approaches define class in terms of a variety of mechanisms of opportunity hoarding, and 3) Marxist approach define class in terms of mechanism of exploitation and domination (p. ix). The report of the APA task force on SES (2007) acknowledged the need for integrative and the state-of-the-art approach to conceptualize and measure SES and social class (p. 27).

However, in the recent past a growing literature in the social psychology of education starts to take into account students' subjective perception of their social class (see for example Ostrove \& Long, 2007; Ostrove, Stewart, \&

\footnotetext{
* O P Jindal Global University
} 
Curtin, 2011; Rubin \& Wright, 2015; Soria, Stebleton, \& Huesman, 2013; Wiederkher, Bonnot, Krauth-Gruber, \& Darnon, 2015). As Keefer, Goode, and Berkel (2015) found the relevance of the class consciousness in the social and political psychology literature, it is shown that the current use of subjective measure misses some important picture about social class. It doesn't give sufficient logic to understand the real experience of which one claims to be cognizant through these measures.

One observation is taken from the Indian society about the subjective perception of being from the higher class because of ones belonging to the upper caste (see Sharma, 1994). However, it was also noticed that social class in terms of objective indicators showed a different picture. Some of the higher caste people, if being low in their social class, still perceived themselves as from high-status group as compared with people belonging to the lower caste background. Harrison (2010) extended the notion of objective and subjective social class as complementary where structural and economic factors complement lived experience. This subjective definition of self, emerging because of group affiliations and identity despite having the consciousness of being high or low on the objectively decided criterion of SES. This shows the need for more criteria's to be included in the SES scale. Also, few reports showed that people in the majority of cases identify themselves as working class even having a job which sociologists consider to be middle class (Harrison, 2010; Ostrove \& Cole, 2003). The effective placing of objective and subjective indicators together with voluntary and involuntary identification was less seen in the mainstream social psychology research in education.

It is imperative to understand that SES measurement on the basis of same sets of criterion may not derive fully the essence of the sociocultural experience of people from the diverse background. Do the people perception of their understanding of social class is authentic or it may turn into exaggerations? (see Adair, 2001; Evans \& Kelley, 2004). In this context, the objective measure of social class may give an important report about the social class standing. In some cases, objective indicators were moderately correlated with the subjective measures (e.g. $\mathrm{r}=0.40$ in Adler, Epel, Castellazzo, \& Ickovics, 2000; $r=0.23$ in Kraus \& Keltner, 2013; r $=0.40$ in Ostrov \& Long, 2007). The recent literature, though, shows the decreasing correlation between naive observers estimate and subjective SES, pointing towards the missing picture. The moderate commonality of variance between objective and subjective measures of social class shows that the measure does not fully translate the individual's subjective experience of their social class. The clarifications about the equivalency of the SES scale applicable to a different cultural context having a different language, value system, beliefs, and practices is debatable. There are some researches in the health domain which appreciated the global applicability of the SES scales, both objective and subjective, where subjective was considered to be more potent predictor (e.g. Singh-Manoux, Marmot, \& Adler, 2005).
Kraus and Stephens (2012) noticed that "social class is rendered meaningful through the contexts that people inhabit over time" (p. 644). Thus, the importance of a subjective understanding of one's class position in the group or society may become relevant. The point of contention here is about the validity of subjective social class indicators and exact point of intersection of objective and assumed subjective indicators (see Rubin et al., 2014). The trend in social psychological literature (e.g. India) assumed the nature of social divisions regarding the interplay of continuous variables and placed its intricacies within the social class context. For example, Verma, Upadhyay and Mishra (2003) tried to understand the development of perceptual exploration and part-whole perception within the socio-cultural context. They sought to explore the nature of development in the upper and the lower continuum of SES. It was interesting to note that the research connected SES with the other social category such as caste, however, in the deficiency context. Research in social psychology of education placed SES configurations as a prominent social category under which other circumstances such as caste, gender, and other social categories were explored (e.g. Rao, Vidya \& Sriramya, 2015; Singh, 1976, 1980; Srivastava, 2003; Srivastava, 2009; see also see also Sinha \& Mishra, 2013; Sinha \& Mishra, 2014; Sinha \& Mishra, 2015; Vahali, 2015). For example, the perception of SES for the people from upper caste background who were wealthy earlier will be different from the perception of lower caste people who are economically wealthy in the present. The possibility of the caste based stigma may not be operating in the same way for both. However, the sense of discrimination and the actual discrimination faced by these two groups is the matter to be looked into the future in the context of social justice. The present article explores the universalistic approach of measuring social class and its reduction to the indicators of SES as a category mistake. Further, it attempts to explore the meaning of quantification of social class and SES in social psychology of education from three trajectories, that is 1) subjectivity and objectivity debate in the measurement of social class in social psychology of education, 2) debates encircling around the position of social psychology and its simplified analysis of social class in terms of objective facets and 3) operationalism of social class and category mistake.

\section{The measurement issues in social class and SES}

The alignment between the social psychological concepts and the actual reality is still an ongoing debate (Haig \& Borsboom, 2012; Schmittmann et al., 2013). The case of SES to denote the corresponding objective social and psychological condition of individual or group is a simplistic and linear appropriation in the social psychological research on education. For example, the definition of SES is based on an integration of few indicators which denotes one's present living status. In social psychological literature in India, it is made 
synonymous with the term social class (Agarwal, 2008; Conger, Conger, \& Martin, 2010; Masthi, Gangaboraiah, Kulkarni, 2013; see also Misra \& Tripathi, 2004). The objective status of the social classification scales and the effort to connect it with the social psychological facets has given an incomplete picture of the social psychological experiences. For example, the observers' perspective offered to understand the effect of SES on students' academic achievement was widely used in the literature. However, the diminishing strength was reported in the metaanalysis (see Sirin, 2005). Pronin, Gilovich, and Ross (2004) discussed the blind spots in the judgment of the reality of one's self and the other, and further added to the hypothesis that objectivity is in the eye of the beholder. It was also discussed in details about the dominance of economic paradigm of SES which is prominent in psychological research. Economists show that SES is a vector approach having both the magnitude and directions. However, the psychological aspects were rejected as subjective and directionless. This questions the interdisciplinary approach to understanding one's psychology by placing one's understanding in the reductivist metatheory? (see Sinha, 2016). Thus, the decreasing statistical relationship between SES and academic achievement convince back to the problematic status of SES and its measurement.

Extending further, the measurement paradigms for understanding any psychological phenomenon utilizes the series of abstraction taken as real. For example, a) in time and space the meaning of attribute may change, b) there is nothing like type-type identity between psychological concept and the actual reality of the phenomenon, and c) the psychological concepts cannot be understood in vacuum but in networked environment (see Zachar, 2015; See also Meehl, 1978). The formative theory about the nature of SES as a latent construct, comprising various indicators complementing one another to give the complete picture is problematic, as the nature of the formative model is also susceptible to change. From the Borsboom (2008) work it can be inferred that the connections of indicators of SES are in direct and possible relations with one another. In this context, Schmittmann et al. (2013) stated that, "a problem with formal theories of dynamical systems is that almost all of the known mathematical results concern deterministic systems" (p. 6).

This holds that the conjoint models available to assess the SES claim through their individual observable connections, about the true determinism and certainty. However, the reduction of social class to the SES indicators only and neglecting the broader concept of social class, or taking it as same, ruptures the philosophical inquiry in the rigid domain of mainstream social psychology and is an overestimation of objectivity. As Schmittmann et al. (2013) pointed that psychology deal with the probabilistic systems and data characterized by high level of noise" (p. 6), it can be scrutinized further to understand the meaning of noise and whether is that an actual noise or important vector having latent interconnected pathways.
The measurement of social class comprises the frequency of categories associated with it. These categories for example, low SES, are obtained from people's response in any social domain and have changing cut off points depending upon the research questions, sample size, participants' identity, and methodology. As compared with concepts in natural science which can be measured through calibrated instruments, the possibility of measurement of social class in a similar way is a complex task. According to Rubin et al. (2014), 'there are no international conventions for measuring social class or SES' (p. 5). The concepts in natural science are reliable across the situations, at least with the same tool, which is amenable to change with the shift in scientific thinking. But the concepts in the social sciences, where the same tool for measuring social class was used sometimes is outdated and are acultural and acontextual. However, the process of revision is available for the tools of measurement, but the revised form does not confirm whether the outcome is real measurement or some epistemological positions (see also Borsboom, 2004). Thus, the reliance on test for establishing the validity of any concept may be due to the validation process and not because of the actual ontological nature of the concept, at least in the domain of social sciences.

The tendency to assign numerals to the subjectively evolved construct in psychology is a criticized by the relativists who conjure up the debates on the objectivity issue adopted by the realists. Let us take one of the indicators of SES that is, income, which relies on the earning and its value measured in the comparative context of income generation. However, it was hardly invoked that income is itself a subjective perception when looked through the lived experience of people. Income provides the emotional and social standing of the individual in a majority of cases where individual's social capitals nurture the accumulated psychological capital. The debates encircling around the position of social psychology of education and its underutilized concept such as social class as a scientifically objective fact in social sciences contests with the interdisciplinary perspective. Some of the debates seem to nurture the epistemological styles of understanding any phenomenon regarding its measurement in psychological sciences (see Kievet et al., 2011; Michell, 2013). The issues of understanding the social psychological concepts in education by assigning numerals and measuring its relationship with other concepts were debated in many forums. One of the arguments is the use of the idea of SES in social psychology. Since SES is one of underutilized concept in social psychological research in education, as it was assumed to have the better role in sociological research rather than in psychological sciences, its scope was limited to its objective nature. SES as an active demographical concept was utilized in research, to study group differences where social psychological concepts were investigated, but its role was more superficial and taken for granted. However, some of the literature in sociology and political sciences paved its way for active involvement in the social psychological literature recently. The concept of SES was 
considered on the basis of consciousness of one's present income, occupation, and educational status, together with its historical awareness regarding one's identification with the available social category. The knowledge of SES gained from the memory of generations, which is the social class, was very much neglected in psychological sciences. Its measurement was assumed to be empirically non-feasible epistemologically, where the whole gamut of one's experiences and collective memory because of social class hierarchy formed the missing picture in social psychological literature. The social psychological research in education, by adopting SES as demographical variable assumed its nature as an empirical construct rather than the concept which has a hidden picture. The decision to operationalize SES by observing the available indicators believed to be portraying the reality of social stratification.

\section{Subjectivity and objectivity debate in the measurement of social class}

Some of the interdisciplinary works related to social class and education have been done in the Indian context (e.g. Sinha, 2013, 2014) where the observers' perspective was looked critically. The problem of psychologism is very much evident in the formulation and measurement of social class in social psychological research in education. The very concept of social class and its intricacies were reduced to the indicators such as occupation, income, and education only giving the incomplete picture. The deeper underlying facets of these individual factors with the subjectivities associated with it were ruled out from the scientific and quantitative circles. The psychological units related to the variations in the contexts such as social class indicators were widely dealt in the literature, however, the thick description (Geertz, 1973) associated with all this context is either very time consuming or outside the scientific reality of social psychological research in education. The myth of assessing the true nature was placed in the paradigms and cultural practices of the scientific community.

Michell (2009), in his chapter on "invalidity in validity' noted that the myth about the measurement of any psychological construct is in actuality a quantitative attribute. In addition, SES is simply not the economics concept derived from the labour market worldviews but has deep seated psychological connotations embedded in the history of one's cultural practices. It can be argued that mental unit is not possible in actuality, however, the unit was assigned to the superficial aspects of the SES construct, and the psychology associated with the social class was separated from its very nature. For example, most of the research in the domains of social psychology in education in India conjectured their problems in terms of the association between objective indicators and psychological constructs. The problem is twofold when we try to connect the two variables, one objectively presented but inherently subjective in nature, in psychological studies, 1) the real correlation is non-conforming to the real life and is limited to the statistical manipulations only, and 2) the conclusion drawn on the basis of statistical correlations is insufficient and need to be complemented with everyday interactions and discourses in the social space (see Zebroski, 2006). The concept of social class was developed to understand facts about the lifestyles, living condition, geographical dominations, capitalization of resources and inequality and divides in terms of accumulation of resources etc. The story of social class was very much missing from the scientifically influenced literature of social psychology of education.

\section{Debates encircling social psychology and use of social class measure}

As discussed, the scientific literature in social psychology of education, linking social class with the educational domain, predominantly presented the universal nature of social class assessed through scales. The categorization of social class was more on the basis of the presence of the quantity of some socioeconomic facets reported on the scale rather than on the basis of something not existing on the scale. According to Hibberd (2014) categories are the conditions or the features of existence or occurrence of anything. However, this is not about the "antecedent circumstances that bring about existence" (see Hibberd, 2014, p. 164) but its inherent nature of being and becoming in the social context. This is contrary to the present status of assessing one's socioeconomic status where researchers in the social psychology of education select the indicators or their aggregation and link it to the psychological constructs. The problem with this type of causality is that it misses the very logic of social class and makes the category mistake by locating the essence in the indicators without respecting its essence of existence in the sociopolitical context. However, it was also observed that many studies related to social class and education, didn't directly approached the relationship but dealt with the intricacies of the conceptual relationships.

In the debates regarding the reservation and affirmative action policies, people from middle class and upper caste background rejected the caste-based affirmative action in favour of economic inequality. The basis for this argument from historically privileged group consciously or unconsciously tries to portray an elusive picture of inequality by neglecting the historical experience of economic and social inequality because of the caste system (see Jodhka, 2012). It was noticed that people from upper caste who were most of the cases better in social and economic positioning have better chances of upward mobility as compared with the people from a lower caste (Sharma, 1994; see also Guru, 2016; Shah, 2017). The estrangement of social class and caste in the social psychology of education literature in India showed the missing picture of the social psychological account. Instead, the role of caste and class are building up on the same premises of degradation of humanity in the name of hierarchy and has taken a permanent picture in the name of essentialism (see Jaspal, 2011; see also Mahalingam, 2003, 2007). 
The difference between the everyday living conditions in terms of belief and values have shaped the psychology of people, thus, displaying their social class (see Argyle, 1993). Recently, Gough and Madill (2012) had given an alternative position where subjectivity was taken out from the stigma of being unobservable and being redundant, as was believed in the positivistic paradigm. They placed the importance of subjectivity in psychological science which was always a subjective phenomenon. That makes psychology a subject of scientific exploration was its assumption of being understood in the public domain, and hence considered more politically an objective science. Except in sociological literature, the concept of social class was treated in a more superficial manner in the social psychological literature, as the whole gamut of social psychology of education is swayed by the mythical paradigm of objectivism, as prominent in traditional scientific thinking. The traditional scientific thinking seems to get motivated by the bold conjectures which are informed by objective knowledge without questioning its status as amenable to change.

The metaphysics of social class as a perception of one's experience through various collective dynamics was not taken into account due to its version of biasedness. The problem which Hibberd (2014) pointed is in the metaphysics and its alignments to the phenomenon under scrutiny by psychologists. The problem here underlies the use of methods claimed to be primarily scientific, however, over-simplistic. The suitability of the method for understanding any phenomenon such as social class effect characterizes its epistemological stance embedded in the paradigm, despite the viewpoints emanating out of the experiences. The question which the social scientists seem to be concerned about is the place of social psychology in sciences and that too is the more mainstream encapsulation of critical debates.

\section{Operationalism of social class and category mistake}

Much literature showed SES as a representative of one's social class. However, from a long time in various cultural contexts and in the various academic forum, it was assumed that social class is dead (see Clark \& Lipset, 1991; Pakulski \& Waters, 1996; Tittenbrun, 2014; see also Herring \& Agarwala, 2008). In the social psychology of education literature, the social class and SES was found to have decreasing or no effect on various domains such as education. If we premise our future discussion on these outcomes, then measurement of SES as a token of one's social class becomes nonsensical. Day (2001) showed that social class has an important effect on our lives and has occupied significant essence of literary and cultural analysis. However, when it comes to the social psychology of education, the meaning and essence of social class are reduced to set of indicators. Is the present use of social class and SES in social psychological research is a category mistake? These we have discussed in the earlier section, however, in the present section, we will exclusively deal with the reductive process involved in the shaping of objective meaning of social class. Before arguing the nature of social class in the social psychology of education domain, the discussion of category mistake and thick description is imperative.

A category mistake is wrong attribution or assignment of quality or attributes to some other category. In other words, it may be a logical fallacy or category mistake (Ryle, 1949), where any concept belonging to a different logical category as something over and above or in addition to a people real life experiences (see Jacquette, 2009). Measurement of SES in social psychological literature adopts a realist approach having a mind-independent stance. However, it is evident through the number of research in philosophy of sciences and measurement that measuring or applying the quantitative feature to the psychological underpinnings, are not natural (Campbell, 1920), are verbal intercourses and have narrow meaning (Reese, 1943). This logic of measurement in psychological science was taken as either metaphorical or as an error in concept building (Maul, Wilson \& Irribarra, 2008). The way quantification of SES corresponds to the actual qualitative contents is the matter of deep scrutiny, as it seems to eliminate the subjective elements like emotions. Though researchers in social psychology attempted to relate objective elements of SES with the psychological variable, it appears to be a paradox of intentionality where the observable objects in the external world are the representations in the mind and connect to varied experiences. For example, the experience of belongingness to any income group after the knowledge of one's objective SES may not necessarily correspond to the actual daily experiences as objectively as it seems. It is imperative to understand the sociocultural meaning of social class by taking objective and subjective aspects together with the discourses on social class through different identity contingencies such as gender, caste, ethnicity etc. This will probably solve the problem of category mistake. Recent literature (Keefer, Goode, \& Berkel, 2015; Stephens, Markus, \& Phillips, 2014; Kraus, Tan \& Tannenbaum, 2013; Kraus \& Stephens, 2012) attempted to go beyond the objective trends of understanding social class in social psychological literature and tried to bring in the subjective understanding of it. The work of Keefer, Goode, and Berkel (2015) shows an antireductionist stance of understanding social class and brought the concept of class consciousness and provided a novel approach towards the use of social class in social psychological literature. Kraus, Tan, and Tannenbaum (2013) provided rank based perspective and suggested that social class is a fundamental mean by which individual is listed on the social ladder of society. This gives way to the shaping of people political attitude and their interaction with the cultural values. The class consciousness and rank based approach offers a perspective for political change taking into the account the perception of hierarchy. However, the internalization of social structure and the classified nature of everyday experience need to be considered into the social psychology of education literature (see Wagner \& McLaughlin, 2015; see also Argyle, 1994). The lack of theoretically based guidance in the use of 
indicators of SES and its identification with psychological experiences is one of the missing pictures in the social psychology of education literature. Wagner and McLaughlin (2015) utilized the concept of Pierre Bourdieu's habitus in more macro and micro level understanding of social class existence in one's consciousness embedded in the power dynamics and communal context of India. As these aspects are underrepresented in the mainstream psychological literature, the effort to enable the exploration of everyday classed experience is the need for future reconciliation of social class measurement in social psychological research in education.

\section{Conclusions and Recommendations}

It can be inferred from the above discussion that utilizing indicators of SES as an accurate measurement of social class is problematic. It is important to have a thick description of the story of social class which can contribute more meaningfully to the social psychology of education literature. The concept of social class in the mainstream psychology shows limited contribution. In other words, it can be assumed that the space provided by the social psychology of education to the graded experience of everyday life is limited. In order to avoid the category mistake, it is imperative to have an understanding of people engagement with the social context and their social networks. The reproduction of the same categorization on the basis of classificatory criteria without giving scope to other identity contingencies like caste, religion, region, languages (in colonial context of India, English is considered to be the language of modern and middle/higher middle class) may lead to limited translation of social experiences.

The paradox of measuring the real element of an entity such as social class is standing on the misunderstood platform. The classification paradox of SES on the basis of sets of indicators boosts the stereotypical assumptions about the social class ladder and provides little scope for the social change. The understanding of social class from the cultural meaning making perspective critically may help to provide a detailed description of class consciousness instead of falling into making category mistake by blindly relying on the operationalism and acontextual measurement. In consequence, doing serious social psychology in India and other cultural context is a need and its cultural elements can't be denied at the cost of few objective indicators or mere perception about one's social class standing without giving serious attention to social class identifications and working class collectivity (see Rubin et al., 2014). Similarly measuring concepts like SES and social class in India cannot be complete if other contexts are not taken seriously or covered in social psychological research in the educational domain. The classification of SES is limited in its approach, and thick description comprising other identity contingencies such as caste, religion, region, language, and gender is needed to avoid the errors of making wrong categorizations. On the basis of above discussions, following points becomes imperative:
1. Utilizing different tools available for assessing SES and their suitability in the social psychology of education: Objective Indicators: composite measures, proxies (see APA Task force on socioeconomic status, 2006) and Subjective Indicators like Mcarthur Ladder (Adler et al., 2000), Class consciousness of participants and researchers.

2. Understanding the discourse on social class (Zebroski, 2006) in different group settings.

3. Capturing the ethnographical accounts of communities.

4. Understanding social class through social network analysis.

\section{References}

Adair, S. (2001). Immeasurable differences: A critique of the measures of class and status used in the General Social Survey. Humanity \& Society, 25, 57-84. doi:10.1177/016059760102500105.

Adler, N.E., Epel, E.S., Castellazzo, G., \& Ickovics, J.R. (2000). Relationship of subjective and objective social status with psychological and physiological functioning: Preliminary data in healthy white women. Health Psychology, 19, 586-592. doi: 10.1037/0278-6133.19.6.586

Agarwal, A.K. (2008). Social Classification: The Need to Update in the Present Scenario. Indian Journal of Community Medicine, 33(1), 50-51.

APA. (2007). Task Force on Socioeconomic Status Report. Washington, DC: American Psychological Association.

Argyle, M. (1994). The psychology of social class. New York: Routledge. Arnold, D.H., \& Doctoroff, G.L. (2003). The early education of socioeconomically disadvantaged children. Annual Review of Psychology, $54,517-545$.

Borsboom, D. (2004). The concept of validity. Psychological Review, 111, 1061-1071.

Borsboom, D. (2005). Measuring the mind: Conceptual issues in contemporary psychometrics. Cambridge: Cambridge University Press.

Borsboom, D. (2008). Psychometric perspectives on diagnostic systems. Journal of Clinical Psychology, 64 (9), 1089-1108.

Campbell, N.R. (1920). Physics, the elements. Cambridge: Cambridge University Press.

Chapin, F.S. (1935). The Measurement of Social Status by Use of a Social Status Scale 1933 (Minneapolis: The University of Minnesota Press).

Clark, T.N., \& Lipset, S.M. (1991). Are social classes dying? International Sociology, 6(4), 397-410. http://iss.sagepub.com/content/6/4/397

Conger, R.D., Conger, K.J., \& Martin, M.J. (2010). Socioeconomic Status, Family Processes, and Individual Development. Journal of Marriage and Family, 72(3), 685-704.

Davey Smith, G., Hart, C., Hole, D., MacKinnon, P., Gillis, C., Watt, G., ... Hawthorne, V. (1998). Education and occupational social class: Which is the more important indicator of mortality risk? Journal of Epidemiology and Community Health, 52, 153-160. doi:10.1136/

Day, G. (2001). Class: the new critical idiom. Oxon: Routledge.

Day, K., Rickett, B., \& Woolhouse, M. (2014). Class dismissed: Putting social class on the critical psychological agenda. Social and Personality Psychology Compass, 8 (8), 397-407.

Desai, Sonalde and Veena Kulkarni. Forthcoming. "Changing Educational Inequalities in India in the Context of Affirmative Action" Demography.

Evans, M.D.R., \& Kelley, J. (2004). Subjective social location: Data from 21 nations. International Journal of Public Opinion Research, 16, 3-38. doi:10.1093/ijpor/16.1.3

Gaines, M.L., \& Davis, S.L. (1990). Accuracy of teacher prediction of elementary school achievement. Paper presented at the Annual Meeting of the American Educational Research Association, Boston, April.

Geertz, C. (1973). The interpretation of cultures. New York: Basic Books.

Gough, B., \& Madill, A. (2012). Subjectivity in psychological science: From problem to prospect. Psychological Methods, 17 (3), 374-384.

Haig, B.D., \& Borsboom, D. (2012). Truth, science, and psychology. Theory \& Psychology, 22(3), 1-18. 
Harackiewicz, J.M., Canning, E.A., Tibbetts, Y., Giffen, C.J., Blair, S.S. Rouse, D.I., \& Hyde, J.S. (2014). Closing the social class achievement gap for first-generation students in undergraduate biology. Journal of Educational Psychology, 106(2), 375-389.

Harrison, E. (2010). Measuring Social Class. In: M. Bulmer, J. Gibbs, \& L. Hyman (Eds.), Social measurement through social surveys: An applied approach (pp. 89-108). Surrey: Ashgate Publishing Limited.

Herring, R.J., \&Agarwala, R. (2008). Whatever happened to class? Reflections from South Asia. Delhi: Daanish Books.

Hibberd, F.J. (2014). The metaphysics of process psychology. Journal of Theoretical and Philosophical Psychology, 34(3), 161-186.

Hochschild, J.L. (2003). Social class in the public schools. Journal of Social Issues, 59, 821-840.

Hoge, R.D. (1983). Psychometric properties of teacher-judgment measures of pupil aptitudes, classroom behaviours and achievement levels. The Journal of Special Education, 17, 401-4.

Jacquette, D. (2009). Philosophy of mind: The metaphysics of consciousness. New York: Continuum.

Jaspal, R. (2011). Caste, Social Stigma and Identity Processes, Psychology and Developing Societies, 23(1), 27-62.

Jodhka, S.K. (2012). Caste. New Delhi: Oxford University Press.

Keefer, L.A., Goode, C., \& Berkel, L.V. (2015). Towards a psychological study of class consciousness: Development and validation of a social psychological model. Journal of Social and Political Psychology, 3(2), 253-290.

Kievit, R.A., Romeijn, J.W., Waldorp, L.J., Wicherts, J.M., H. Steven Scholte \& Borsboom, D. (2011). Mind the gap: A psychometric approach to the reduction problem. Psychological Inquiry, 22, 67-87.

Kraus, M.W., \& Keltner, D. (2009). Signs of socioeconomic status: A thinslicing approach. Psychological Science, 20, 99-106.

Kraus, M.W., \& Stephens, N.M. (2012). A road map for an emerging psychology of social class. Social and Personality Psychology Compass, 6(9), 642-656.

Kraus, M.W., Tan, J.J.X., Tannenbaum, M.B. (2013). The social ladder: A rank-based perspective on social class. Psychological Inquiry, 24(2), 81-96.

Kraus, M.W., \& Stephens, N.M. (2012). A roadmap for an emerging psychology of social class. Social and Personality Psychology Compass, 6, 642-656.

Lareau, A., \& Conley, D. (2008). Social class: How does it work? New York, NY: Russell Sage Foundation.

Mahalingam, R. (2003). Essentialism, Culture, and Power: Representations of Social Class. Journal of Social Issues, 59 (4), 733-749.

Mahalingam, R. (2007). Essentialism, power and the representation of social categories: An integrated perspective. Human Development, 50 (6), 300-319.

Masthi, N.R.R., Gangaboraiah., Kulkarni, P. (2013). An Exploratory Study on Socio Economic Status Scales in a Rural and Urban Setting. Journal of Family Medicine and Primary Care, 2(1), 69-73.

Maul, A., Wilson, M., \& Irribarra, T. (2013). On the conceptual foundations of psychological measurement. Journal of Physics: Conference Series, 459, 1-6.

McLoyd, V.C., Jayaratne, E., Ceballo, R., \& Borquez, J. (1994). Unemployment and work interruption among African American single mothers: Effects on parenting and adolescent socioemotional functioning. Child Development, 65, 562-589.

Meehl, P.E. (1978). Theoretical risks and tabular asterisks: Sir Karl, Sir Ronald, and the slow progress of soft psychology. Journal of Consulting and Clinical Psychology, 46, 806-834.

Michell, J. (2009). Invalidity in validity. In: R.W. Lissitz (Ed.), The concept of Validity. Revisions, new directions and applications (pp. 111-133). Charlotte, N C: Information Age Publishing.

Michell, J. (2013). Constructs, inferences, and mental measurement. New Ideas in Psychology, 31, 13-21.

Misra, G., \& Tripathi, K.N. (2004). Psychological dimensions of poverty and deprivation. In: J. Pandey (Ed.), Psychology in India Revisited: Developments in the discipline (pp. 118-215), New Delhi: Sage.

Nagel, T. (1974). What is it like to be bat? The philosophical Review, $83(4), 435-450$

Nettelbeck, T., \& Wilson, C. (2010). Intelligence and IQ. In: K. Wheldall (Ed.), Developments in educational psychology (pp. 30-52). London \& New York: Routledge.
Ostrove, J.M., \& Cole, E.R. (2003). Privileging class: Towards a critical psychology of social class in the context of education. Journal of Social Issues, 59(4), 677-692.

Ostrove, J.M., \& Long, S.M. (2007). Social class and belonging: Implications for college adjustment. Review of Higher Education, 30, 363-389.

Ostrove, J.M., Stewart, A.J., \& Curtin, N.L. (2011). Social Class and Belonging: Implications for Graduate Students' Career Aspirations. The Journal of Higher Education, 82(6), 748-774

Pakulski, J., \& Walters, M. (1996). The Death of Class. London: Sage.

Pronin, E., Gilovich, T., \& Ross, L. (2004). Objectivity in the eye of the beholder: divergent perceptions of bias in self versus others. Psychological Review, 111(3), 781-799.

Rao, G.P., Vidya, K.L., \& Sriramya, V. (2015). The Indian "girl" psychology: A perspective. Indian Journal of Psychiatry, 57(Suppl 2), S212-S215. http://doi.org/10.4103/0019-5545.161480

Reese, T.W. (1943). The application of the theory of physical measurement to the measurement of psychological magnitudes, with three experimental examples. Psychological Monographs, 55, 6-20.

Rubin, M., \& Wright, C.L. (2015). Age Differences Explain Social Class Differences in Students' Friendship at University: Implications for Transition and Retention. Higher Education, 70, 427-439. doi: 10.1007/s10734-014-9844-8

Rubin, M., Denson, N., Kilpatrick, S., Matthews, K.E., Stehlik, T., \& Zyngier, D. (2014). I am working class: Subjective self definition as a missing measure of social class and socioeconomic status in higher education research. Educational Researcher, 43(4), 196-200.

Ryle, G. (1949). The concept of mind. London: Penguin.

Schmittman, V.D., Cramer, A.O.J., Waldorp, L.J., Epskamp, S., Kievit, R.A., \& Borsboom, D. (2013). Deconstructing the construct: A network perspective on psychological phenomenon. New Ideas in Psychology, 31(1), 43-53.

Scott, J., \& Leonhardt, D. (2005, May 15). Class in America: Shadowy lines that still divide. The New York Times, pp. 16-18.

Sharma, K.L. (1994). Caste and class in India. New Delhi: Rawat Publication.

Singh, A.K. (1976). Social disadvantage, intelligence and scholastic achievement (Report on the Developmental Norms Project). New Delhi: NCERT.

Singh, A.K. (1980). Social disadvantage and academic achievement. Social Change, 10, 15-18.

Singh-Manoux, A., Marmot, M.G., \& Adler, N.E. (2005). Does Subjective Social Status Predict Health and Change in Health Status Better Than Objective Status? Psychosomatic Medicine, 67, $855-861$.

Sinha, C. (2016). Rethinking interdisciplinarity in social sciences: Is it a new revolution or paradox? Journal of Interdisciplinary Studies in Education, 4(2), 44-66.

Sinha, C., \& Mishra, A. (2014). The illusion of social class identity and academic performance: Exploring the role of father education as an indicator of socioeconomic status. Journal of Psychological and Educational Research, 22(1), 34-56.

Sinha, C., \& Mishra, A.K. (2015). Rethinking the place of socioeconomic status identity in students' academic achievement. European Journal of Psychology \& Educational Studies, 2, 36-42. doi: $10.4103 / 2395-2555.170724$

Sinha, C., \& Mishra, A.K. (2013). Revisiting social class: exploring stereotype threat effect on intellectual performance of school students. Journal of Educational Sciences \& Psychology, XLV(1), 133-146.

Sirin, S.R. (2005). Socioeconomic Status and Achievement: A meta-analytic review of research. Review of Educational Research, 75(3), 417-453.

Soria, K.M., Stebleton, M.J., \&Huesman, R.L. (2013). Class counts: Exploring differences in academic and social integration between working-class and middle/upper-class students at large, public research universities. Journal of College Student Retention: Research, Theory and Practice, 15, 215-242. doi: 10.2190/CS.15.2.e

Srivastava, A. (2003). Resilience in low income working people. In U. Vindhya (Ed.), Psychology in India: Intersecting Crossroads (pp. 202-220). New Delhi: Concept.

Srivastava, A.K. (2009). Dynamics of schooling. In: G. Mishra (Ed.), Psychology in India: Social and Organizational Processes (Vol. 2, 
pp. 357-406). Indian council of social science research. Pearson: New Delhi.

Stephens, N.M., Markus, H.R., \& Fryberg, S.A. (2012). Social Class Disparities in Health and Education: Reducing Inequality by Applying a Sociocultural Self Model of Behaviour. Psychological Review, 119(4), 723-744.

Stephens, N.M., Markus, H.R., \& Phillips, T. (2014). Social class culture cycles: How three gateway contexts shape selves and fuel inequality. Annual Review of Psychology, 65, 611-634.

Stevens, S.S. (1946). On the theory of scales of measurement. Science, $103,667-680$.

Sujatha, K. (2002). Education among scheduled tribes. In: R. Govinda (ed.), India Education Report: A Profile of Basic Education. New Delhi: Oxford University Press. Retrievd from: http://ced-india.org/ docsweb/Education/Scanned_material/analysis_Tribals.pdf.

Tajfel, H. (1981). Human groups and social categories: Studies in social psychology. London and New York: Cambridge University Press.

The Probe Team. (1999). Public Report on Basic Education in India. New Delhi: Oxford University Press.

Tittenbrun, J. (2014). The death of class? Retrieved from (file://C:/Users/ pc/Downloads/The\%20death\%20of\%20class\%20...\%20(1).pdf)

Vahali, H.O. (2015). 'Could I become human by engaging with your un(der)stated life?' Struggles from a psychoanalytical perspective on listening to the mentally ill poor person and the homeless poor. Psychology and Developing Societies, 27(2), 231-253.
Vanneman, Reeve, James Noon, Sonalde Desai, Mitali Sen and Abusaleh Shariff. (2006). Social Capital in India: Caste, Tribe and Religious Variation in Social Networks. Paper presented at the PAA Meetings, Los Angeles.

Verma, M., Upadhyay, S.K., \& Mishra, R.C. (2003). Role of socioeconomic background in the development of perceptual exploration and part-whole perception. In: U. Vindhya (Ed.), Psychology in India: Intersecting Crossroads (pp. 108-127). New Delhi: Concept.

Wagner, B., \& McLaughlin, K. (2015). Politicizing the psychology of social class: The relevance of Pierre Bourdieu's habitus for psychological research. Theory \& Psychology, 25(2), 202-221.

White, K.R (1982). The relation between socioeconomic status and academic achievement. Psychological Bulletin, 91, 461-81.

Wiederkher, V., Bonnot, V., Krauth-Gruber, S., \& Darnon, C. (2015). Belief in school meritocracy as a system justifying tool for low status students. Frontiers in Psychology, 6, 1-10.

Winne, P.H., \& Nesbit, J.C. (2010). The psychology of academic achievement. Annual Review of Psychology, 61, 653-678.

Wright, E.O. (2015). Understanding Class. London: Verso

Zachar, P. (2015). Popper, Meehl, and Progress: The Evolving Concept of Risky Test in the Science of Psychopathology. Psychological Inquiry, 26, 279-285.

Zebroski, J.T. (2006). Social class as discourse: Mapping the landscape of class in rhetoric and composition. Journal of Advanced Composition, 26, 513-584. 